\title{
Petrology and geochemistry of a boninite dyke from the western Bastar craton of central India
}

\author{
Biswajit Hazarika ${ }^{1}$, D B Malpe ${ }^{1}$ and Ashish Dongre ${ }^{2, *} *_{\odot}$ \\ ${ }^{1}$ Department of Geology, RTM Nagpur University, Nagpur 440 001, India. \\ ${ }^{2}$ Department of Geology, Savitribai Phule Pune University, Pune 411 007, India. \\ *Corresponding author.e-mail: andongrey@gmail.com
}

MS received 10 January 2018; revised 5 April 2018; accepted 29 April 2018; published online 25 January 2019

The Dongargarh Supergroup along with the basal Amgaon Gneissic Complex constitutes the northwestern part of the central Indian Bastar craton. In the present study, we report a new finding of a boninite dyke intruded in the Amgaon gneisses of this area. The dyke composed of mainly pyroxenes, amphiboles and subordinate amount of plagioclase. The higher contents of $\mathrm{SiO}_{2}(51-54$ wt.\%), $\mathrm{MgO}$ (12-14 wt.\%), Ni (375-473 ppm), Cr (1416-1580 ppm) and very low $\mathrm{TiO}_{2}(0.2-0.4$ wt.\%) are consistent with the boninite nature of the dyke as well as the unevolved primary nature of the source magma. The extraordinarily high $\mathrm{CaO}$ content (15.97-17.7 wt.\%) with higher $\mathrm{CaO} / \mathrm{Al}_{2} \mathrm{O}_{3}(3.13-3.96)$ ratios classifies it as high-Ca boninite. The trace element ratios including $\mathrm{Zr} / \mathrm{Ti}, \mathrm{Ti} / \mathrm{V}, \mathrm{Ti} / \mathrm{Sc}$ and $\mathrm{Ti} / \mathrm{Yb}$ further show its geochemical similarity with the Archaean boninite. The dyke also shows negative high-field strength element $(\mathrm{Nb}, \mathrm{Ta}$ and $\mathrm{Ti}$ ) anomalies which are the characteristics of the boninite rocks reported elsewhere and along with the enriched light rare earth element pattern, it shows more affinity particularly with the northern Bastar boninite dyke. The mineralogical and geochemical similarities of the boninite dykes from the Bastar craton indicate a widespread boninitic event during the Palaeoproterozoic having a similar origin. These boninite dykes indicate the preservation of subduction-related signatures in the lithospheric mantle beneath the Bastar craton at the time of its evolution or may be during the convergence of the Bastar and Bundelkhand cratons.

Keywords. Boninite; petrology; subduction; Bastar craton; central India.

\section{Introduction}

Boninites are relatively rare, high $\mathrm{MgO}(>8 \mathrm{wt} . \%)$ and low $\mathrm{TiO}_{2}(<0.5$ wt.\%) basaltic-to-andesitic rocks (Le Bas 2000). They are thought to form in the supra-subduction zone tectonic environment, derived from the shallow melting of a highly depleted hydrous mantle, fluxed with water from subducted slabs (e.g., Hickey and Frey 1982; Beccaluva and Serri 1988; Crawford et al. 1989; Stern and Bloomer 1992). However, they are also reported to form at the extended fore-arc with a scenario of propagation of back-arc spreading centres into the fore-arc regions (e.g., Manikyamba et al. 2005; Meffre et al. 2012), as well as the mantle plume interaction with the arc can also

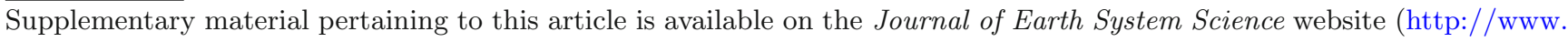
ias.ac.in/Journals/Journal_of_Earth_System_Science). 
be a possible scenario for the boninite formation (Falloon et al. 2007, 2008). The atypical geochemical characteristics of boninite point to its unusual genesis that includes high temperature $\left(>1100^{\circ} \mathrm{C}\right)$ and involvement of subduction fluid in metasomatism of the shallow harzburgitic mantle, which was previously depleted by extensive extraction of tholeiitic melt (Crawford et al. 1989). The boninitic affinity of parental magmas for two of the world's largest platinum-group element deposits, the Bushveld igneous complex of South Africa and Stillwater complex of Montana, USA, manifest its economic importance (Crawford et al. 1989).

In the context of Indian subcontinent, boninites are reported from most of the cratons likewise the Singhbhum craton (Mir et al. 2015), Dharwar craton (Manikyamba et al. 2005; Ganguly et al. 2016) and Bastar craton (Srivastava 2006, 2008; Subba Rao et al. 2008a, b; Chalapathi Rao and Srivastava 2009). The Bastar craton contains the reports of the emplacement of boninitic rocks mostly in its southern and northern parts (Srivastava 2006; Subba Rao et al. 2008a, b), whereas a boninitic dyke is also reported from the Dongargarh Supergroup of rocks (Chalapathi Rao and Srivastava 2009). The aim of the present study is to report the occurrence of a boninite dyke for the first time from the western Bastar craton intruded in the Amgaon gneisses. The paper further discusses the geodynamic significance of this dyke based on the comprehensive petrological and geochemical studies.

\section{Geological setting}

The Archaean Bastar craton is one of the central Indian cratonic domains, which was separated from the Bundelkhand craton by the central Indian tectonic zone (CITZ) (Roy et al. 2000). The roughly rectangular-shaped Bastar craton, located south of the CITZ, is limited by NWSE trending Mahanadi and Godavari rifts, ENEWSW trending Narmada-Son rift and Eastern Ghats Mobile Belt. These rifts are considered to be formed during Precambrian (e.g., Naqvi and Rogers 1987; Srivastava et al. 2004). It lies in the ENE of the Dharwar craton, separated later by the Godavari rift. The overall tectonic trend of the craton is north-south, in contrast to ENEWSW to east-west trend recorded in the Bundelkhand craton (Yedekar et al. 1990; Roy et al. 2000). The craton comprises granitoids and mafic rocks, tonalite-trondhjemite gneisses, supracrustal rocks including greenstone belts and intrusive granitic plutons and unmetamorphosed Neoproterozoic sediments (Crookshank 1963; Ramakrishnan 1990; Chaudhuri et al. 2002; Srivastava et al. 2004; Ramakrishnan and Vaidyanadhan 2008). The craton has experienced different mafic magmatic events (volcanics and intrusives) during Precambrian that are reported from the different parts of the craton (Srivastava and Gautam 2009). Mafic volcanics are mostly represented by the basalts and basaltic andesites (Krishnamurthy et al. 1990; Neogi et al. 1996). However, the low-Ti and high$\mathrm{Ti}$ volcanics and siliceous high magnesium basalts (SHMB) are also reported from the Palaeoproterozoic Dongargarh Supergroup (Asthana et al. 1996; Sensarma et al. 2002). Mafic intrusives of different ages and compositions are extensively reported from the southern, central and northern parts of the craton (e.g., Ramachandra et al. 1995; Srivastava and Singh 2004; Subba Rao et al. 2004, 2008a; Srivastava 2006; Mondal et al. 2007; French et al. 2008; Hussain et al. 2008; Srivastava and Gautam 2008, 2009, 2012; Ratre et al. 2010; Das et al. 2011; Srivastava et al. 2011; Gautam and Srivastava 2011; Sinha et al. 2011; Pisarevsky et al. 2013). The intrusives include sub-alkaline mafic dykes i.e., Bastar Dykes 1 (BD1 of $\sim 2.7 \mathrm{Ga}$ ) and Bastar Dykes 2 (BD2 of 1.88-1.89 Ga), boninitenorite dykes $(\sim 2.1 \mathrm{Ga})$ from the southern part (French et al. 2008; Srivastava 2008; Srivastava et al. 2011), Bhanupratappur-Keshkal dykes from the central part (Ramachandra et al. 1995; Gautam and Srivastava 2011; Srivastava and Gautam 2012) and Dongargarh, Chhura, Lakhna $(\sim 1.44 \mathrm{Ga})$ and Bandimal $(\sim 1.42 \mathrm{Ga})$ dykes from the northern part of the craton (Ratre et al. 2010; Das et al. 2011; Sinha et al. 2011; Pisarevsky et al. 2013; Srivastava and Gautam 2015).

The boninite of the present study $\left(21^{\circ} 28^{\prime} 40.3^{\prime \prime} \mathrm{N}\right.$ and $80^{\circ} 29^{\prime} 56^{\prime \prime} \mathrm{E}$ ) found as intrusive within the Amgaon gneisses of western Bastar craton (figure 1). This part of the craton mostly comprises the Amgaon Group and Dongargarh Supergroup of rocks. The Amgaon Group is composed of psammitic-psamopelitic metamorphite alternating with metabasic lavas. Granite gneisses along with TTG gneissic phase forms basement for the Dongargarh Supergroup (Sarkar et al. 1981; Rao 1981; Krishnamurthy et al. 1988; Sarkar 1994; Wanjari et al. 2005; Ramakrishnan and Vaidyanadhan 2008). The Neoarchean-Palaeoproterozoic Dongargarh Supergroup comprises older bimodal volcanics 


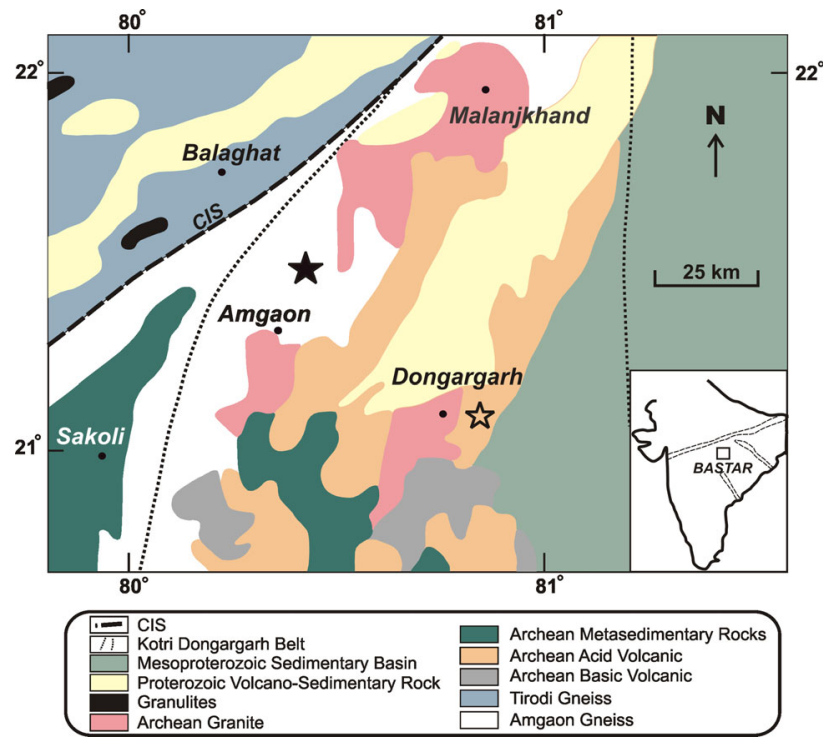

Figure 1. Geological map of the western Bastar craton, central India (after Asthana et al. 2017). Black asterisk represents the location of the present boninite dyke and the other one represents the location of Dongargarh boninite (Chalapathi Rao and Srivastava 2009).

of the Nandgaon Group and younger volcanosedimentary sequence of the Khairagarh Group divided by an unconformity after the Dongargarh granitoid emplacement (Krishnamurthy et al. 1990).

\section{Analytical technique}

The mineral chemistry was determined using a Cameca SX 100 electron probe micro-analyser (EPMA) at the University of Johannesburg, South Africa. Quantitative mineral analyses were operated at $20 \mathrm{kV}$ accelerating voltage, $20 \mathrm{nA}$ beam current and $1 \mu \mathrm{m}$ beam diameter with variable (12$40 \mathrm{~s}$ ) counting time on the peak, based on the element. The standards used for the calibration of EPMA were natural jadeite $(\mathrm{Na})$, olivine $(\mathrm{Mg})$, almandine $(\mathrm{Al})$, diopside $(\mathrm{Si})$, orthoclase $(\mathrm{K})$, wollastonite $(\mathrm{Ca})$, rhodonite $(\mathrm{Mn})$ and haematite $(\mathrm{Fe})$, and synthetic pure oxides for $\mathrm{TiO}_{2}, \mathrm{Cr}_{2} \mathrm{O}_{3}$ and $\mathrm{NiO}$. Elements were measured on their $\mathrm{K} \alpha$ lines. The 'X-PHI' method was used for the matrix correction (Merlet 1994). Backscattered electron (BSE) imaging was performed on the same instrument using the same conditions of acceleration voltage and beam current.

For the whole-rock chemical analyses, powdered rock samples were milled in HERZOG swing grinding mill (Model HSM-100) and were analysed using the fused disc and the borate fusion method. Major element oxides for five samples were determined by inductively coupled plasma-emission spectrometry technique (SpectroCiros-CCD) at Acme Laboratories Canada and wavelength dispersive X-ray fluorescence spectrometry at Wadia Institute of Himalayan Geology, Dehradun. Trace elements (including rare earth elements (REEs)) were analysed by inductively coupled plasma-mass spectrometry (Perkin Elmer SCIEX, Model ELAN ${ }^{\circledR}$ 9000). Instruments were calibrated using the standard reference materials and internal standards, and accuracy was monitored using the certified reference materials using the fundamental parameters model. The analyses of the standard reference materials are given in table S1 (online supplementary material) to show the accuracy and precision of the present data.

\section{Petrography}

Petrographic studies reveal fine-to-medium-grained nature of the rock. Mineralogically, it mainly consists of pyroxenes with minor amounts of amphiboles and plagioclase (figure 2). Pyroxenes are represented by subhedral-to-anhedral grains of both clinopyroxenes (cpx) and orthopyroxenes (opx). Clinopyroxenes are dominant than orthopyroxenes. Patches of orthopyroxenes occurring as relict granulations in clinopyroxenes suggest their earlier formation. At some places, orthopyroxenes are replaced by amphiboles. Chloritisation effects are not predominant. Plagioclase grains occur as intercumulus by occupying the spaces between pyroxene grains. It shows albite twinning and some twin lamellae are deformed or disappeared, indicating the deformation of the grains (figure 2). Saussaritisation and sericitisation at the grain boundaries suggest an alteration.

\section{Mineral chemistry}

The mineral chemical compositions of clinopyroxenes and amphiboles are given in table 1.

\subsection{Clinopyroxene}

Clinopyroxene is a major mineral constituent of the dyke. It shows a narrow range of $\mathrm{Mg}$ number $[\mathrm{Mg} \#=\mathrm{Mg} /(\mathrm{Mg}+\mathrm{Fe})$ atomic $]$ between 0.76 and 0.78 and is mostly diopside in composition $\left(\mathrm{Wo}_{48.5-50.1}-\mathrm{En}_{38.2-39.2}-\mathrm{Fs}_{11.5-12.3}\right)$. These clinopyroxenes are more enriched in $\mathrm{Ca}$ compared 

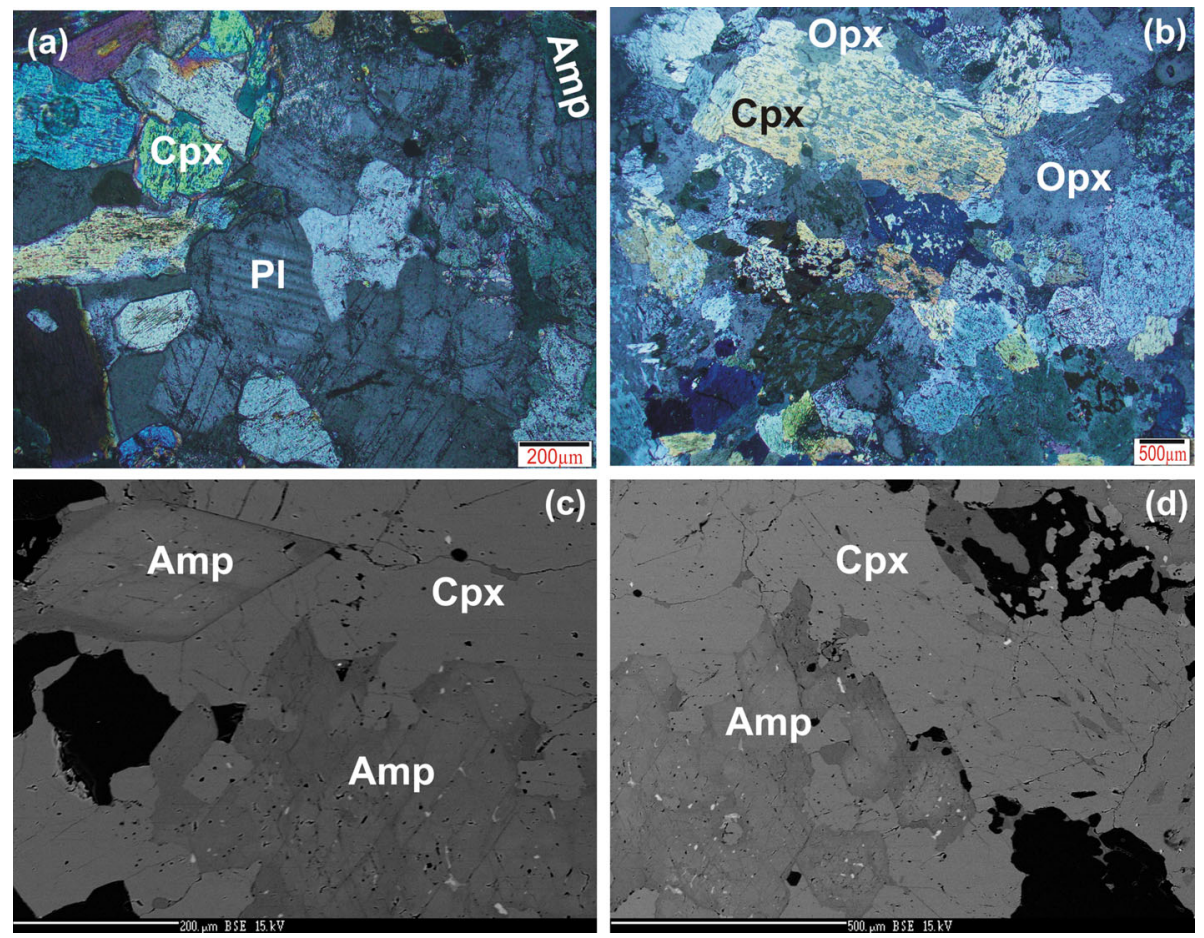

Figure 2. (a) Photomicrograph showing the presence of Cpx, Pl and Amp; (b) patches of Opx are visible in Cpx, at some places Opx breaks down to amphibole; (c and d) BSE images of present dykes showing Cpx and Amp grains. Abbreviations: $\mathrm{Pl}$, plagioclase; Cpx, clinopyroxene; Amp, amphibole.

to the clinopyroxenes of the mafic Deccan basaltic rocks (Melluso and Sethna 2011) and are showing more similarity with the composition of the Dongargarh boninitic dyke (figure 3). The extremely low $\mathrm{TiO}_{2} \quad(0.02-0.09$ wt.\%) content of clinopyroxene is also similar to the boninitic dyke of the Dongargarh Supergroup (Chalapathi Rao and Srivastava 2009).

\subsection{Amphibole}

The amphiboles of the present study are mainly Ca-bearing and consist of high (>5 wt.\%) and low alumina $(<5$ wt. $\%)$ variety. They are classified as actinolite and hornblende on the basis of $\mathrm{Mg} /(\mathrm{Mg}+$ $\mathrm{Fe}$ ) and Si (a.p.f.u.) contents (Leake et al. 1997) (figure 4). Chalapathi Rao and Srivastava (2009) reported the amphiboles of actinolite and hornblende composition from the boninitic dyke of Dongargarh Supergroup rocks, which are mostly showing similar composition with little enrichment in $\mathrm{Mg}$ content.

\section{Bulk rock geochemistry}

The major and trace element compositions of the studied dyke along with the average compositions of earlier reported boninite dykes from the
Bastar craton of the central India (Srivastava 2006; Subba Rao et al. 2008a, b; Chalapathi Rao and Srivastava 2009), from Gadwal greenstone belt of south India (Manikyamba et al. 2005) and the Archaean boninites (Smithies et al. 2004) are given in table 2. The characteristic higher $\mathrm{SiO}_{2}(>51.8-$ 53.6 wt.\%) and $\mathrm{MgO}(>12.2-14.3$ wt.\%) contents and higher $\mathrm{Mg}$ number $(\mathrm{Mg} \#=\mathrm{Mg}+\mathrm{Fe} / \mathrm{Mg})$ of 73-76 shown by the present dykes are similar to the earlier reported worldwide boninitic rocks. The high Mg-rock classification schemes recommended by IUGS (Le Bas 2000), based on the total alkali vs. $\mathrm{SiO}_{2}$ content, classify the present samples as boninites and are showing very similar composition to the earlier reported Bastar boninites (Srivastava 2006; Subba Rao et al. 2008a, b; Chalapathi Rao and Srivastava 2009) (figure 5). The dyke shows extremely elevated $\mathrm{CaO}$ content (15.917.7 wt.\%) as compared to the earlier reported boninites from the Bastar craton. The $\mathrm{SiO}_{2}, \mathrm{Al}_{2} \mathrm{O}_{3}$ and $\mathrm{Na}_{2} \mathrm{O}$ contents show a negative correlation with $\mathrm{MgO}$, while the $\mathrm{TiO}_{2}$ increases with the increasing $\mathrm{MgO}$ (figure $6 \mathrm{a}-\mathrm{d}$ ), which is consistent with the fractionation trends in the mafic magma and with the other boninites. The normal trends of major oxides with $\mathrm{MgO}$ also suggest their immobility during alteration or metamorphic processes. 


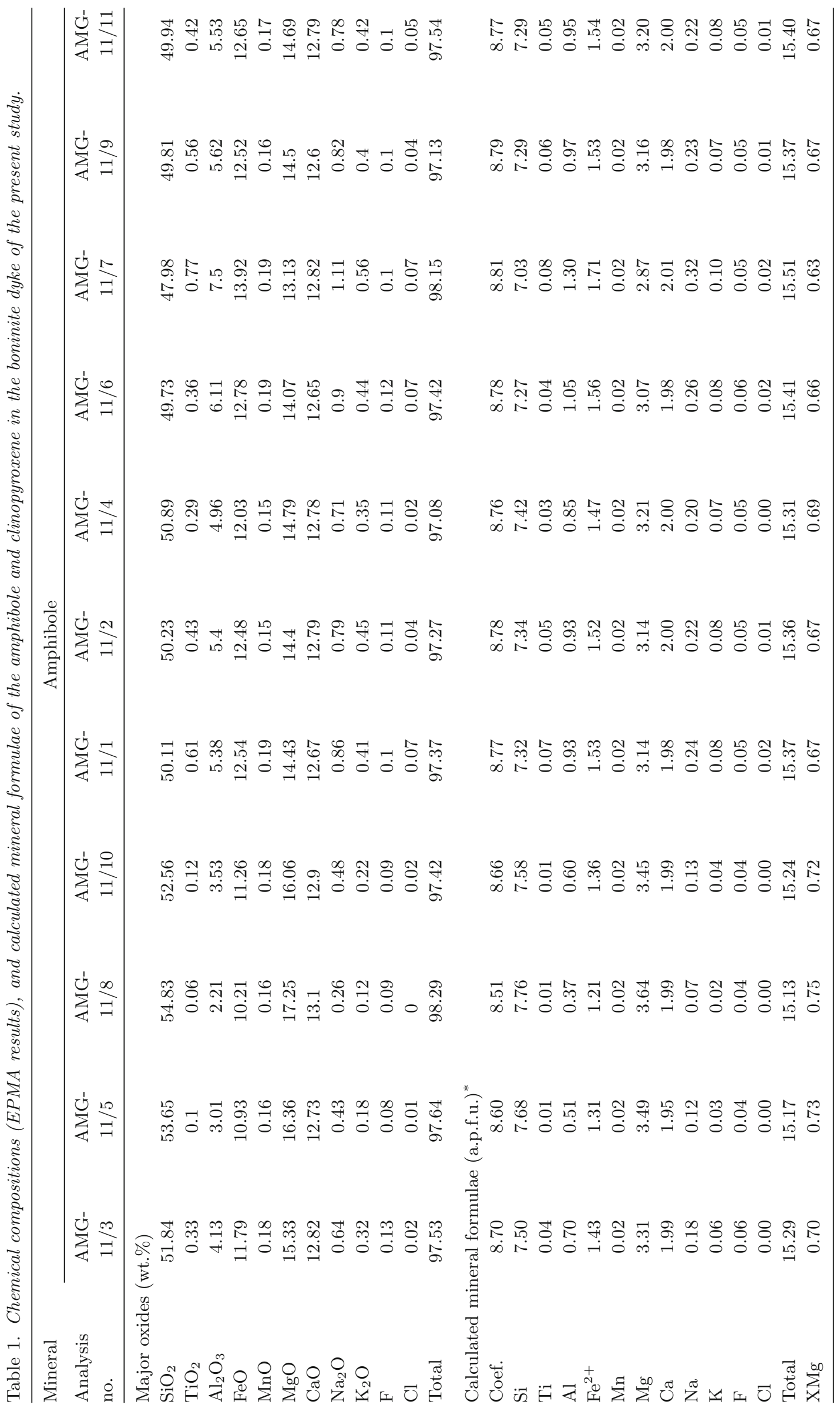




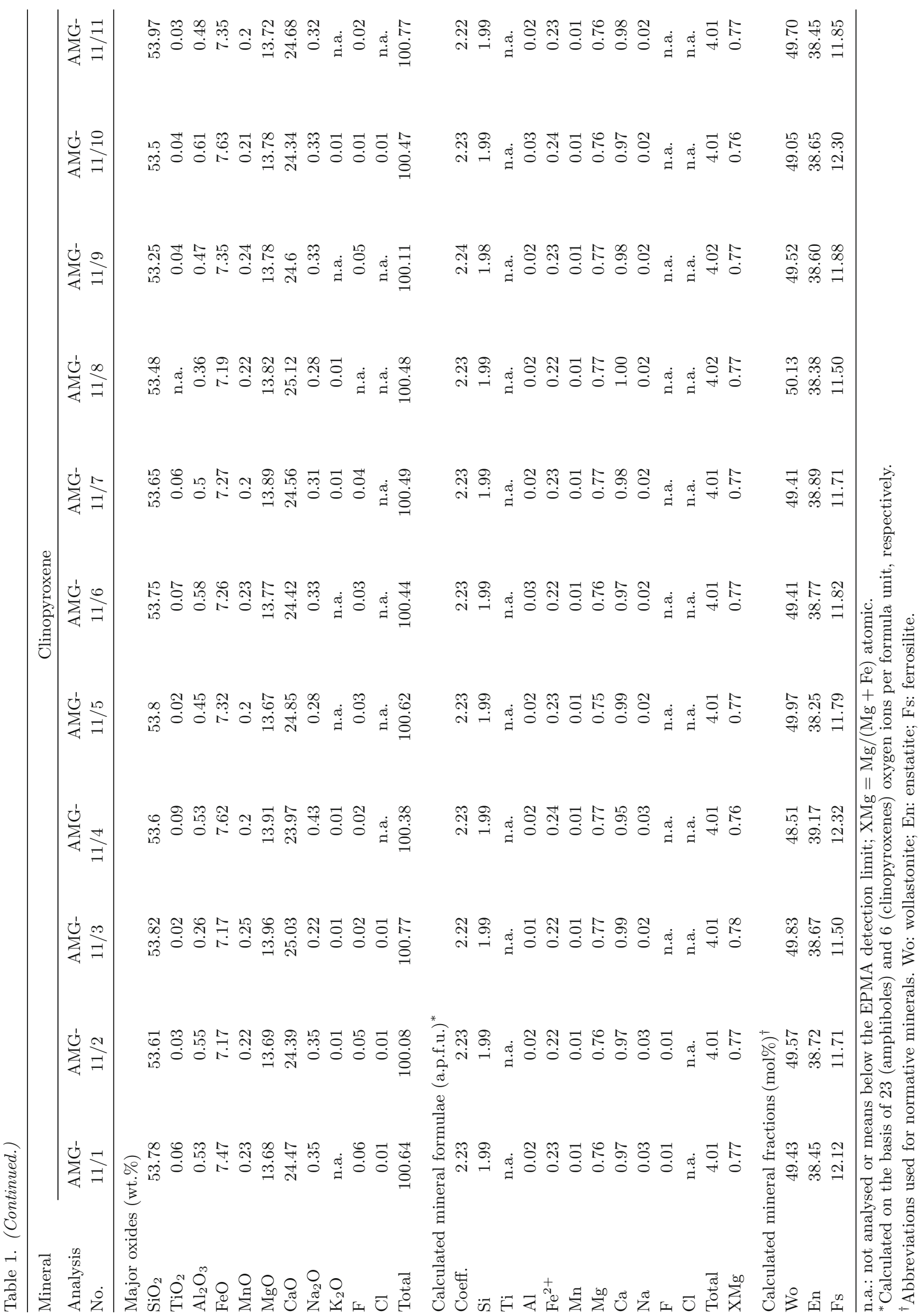




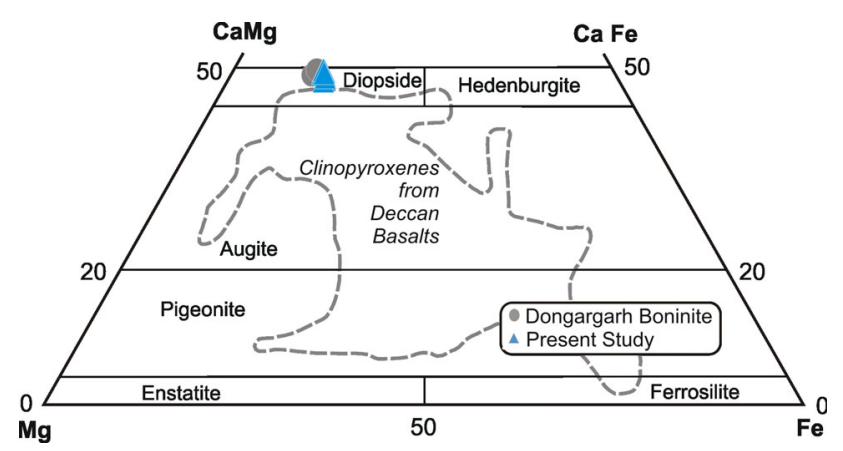

Figure 3. Composition of pyroxenes in $\mathrm{Ca}-\mathrm{Mg}-\mathrm{Fe}$ diagram. Deccan basalts pyroxenes field is taken from Melluso and Sethna (2011) and data for Dongargarh boninites from Chalapathi Rao and Srivastava (2009).

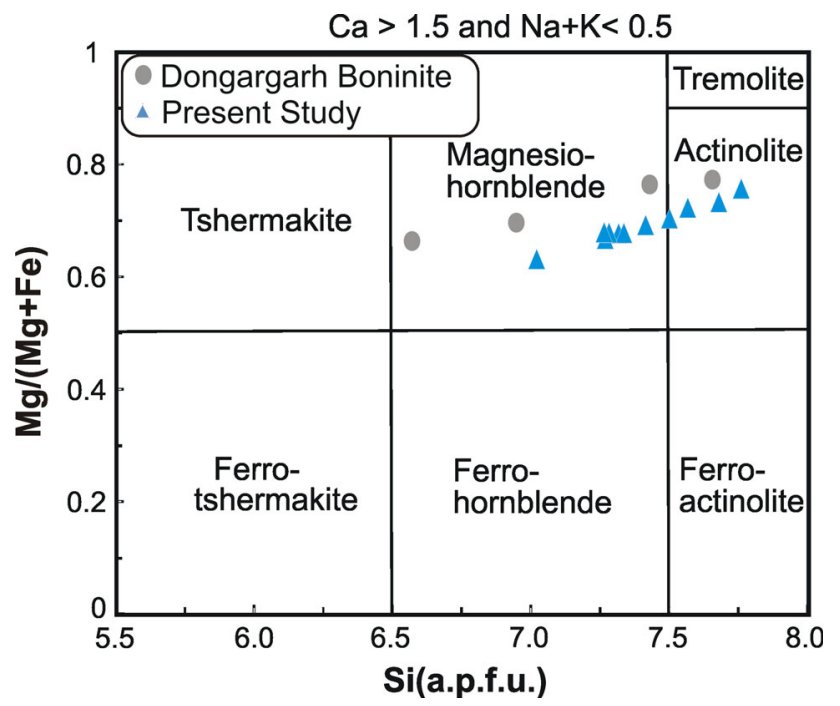

Figure 4. Compositional variation and classification of amphiboles (after Leake et al. 1997). Data for Dongargarh boninites from Chalapathi Rao and Srivastava (2009).

The present dyke shows high amounts of compatible trace elements such as Sc (49-50 ppm), V (228-230 ppm), Cr (1416-1580 ppm) and $\mathrm{Ni}$ (375-473 ppm). Nickel shows a positive correlation with $\mathrm{MgO}$ (figure 7a) like other boninite rocks and is consistent with the fractionation of the mafic magma. The $\mathrm{Zr}, \mathrm{Ti}, \mathrm{Nb}$ and $\mathrm{V}$ concentrations (figure $7 \mathrm{~b}-\mathrm{d}$ ) are much more similar to the other reported boninites from Bastar and Dharwar cratons and particularly to the Archaean boninites (Smithies 2002). Nb concentration is between 2.2 and $2.7 \mathrm{ppm}$. The very low $\mathrm{Nb}$ values are reported from the Dongargarh boninites (0.18-0.23 ppm) (Chalapathi Rao and Srivastava 2009), whereas higher values (5-6 ppm) are known from the Bastar (Srivastava 2006; Subba Rao et al. 2008a, b) and Gadwal boninites (Manikyamba et al. 2005). Primitive mantle normalised multi-element diagrams (normalising values after Sun and McDonough 1989) show enrichment of large ion lithophile elements (LILEs) as compared to high-field strength elements (HFSEs) with prominent negative anomalies at $\mathrm{Nb}, \mathrm{Ta}, \mathrm{Zr}$, Hf and Ti (figure 8b). Chondrite normalised REE patterns (Sun and McDonough 1989) (figure 8a) show an enriched trend of light REEs (LREE) and a relatively depleted trend of heavy REEs (HREE) with distinct negative $\mathrm{Eu}$ anomaly indicating plagioclase fractionation during the evolution of the melt.

\section{Discussion}

The studied dyke shows higher $\mathrm{MgO}$ content (i.e., $>12$ wt.\%) and compatible trace elements (Sc, V, $\mathrm{Cr}$ and $\mathrm{Ni}$ ) which indicates the primary nature of its source magma. The higher amount of $\mathrm{MgO}$ and lower $\mathrm{Al}_{2} \mathrm{O}_{3}, \mathrm{~K}_{2} \mathrm{O}, \mathrm{Na}_{2} \mathrm{O}, \mathrm{Rb}$ and $\mathrm{Sr}$ demonstrate that the dyke is not affected by the significant crustal contamination. The intrusion of dyke in the gneisses would have been elevated these element concentrations on the event of crustal contamination. The $\mathrm{Al}$ and $\mathrm{Ti}$ contents of boninites along with the trace elements such as Th, Nb, Ta, Zr, Hf, Y, Sc and V are considered to be least susceptible to alteration and conventionally used to differentiate various high- $\mathrm{Mg}$ mafic rocks such as boninite, high-Mg norite, SHMB and komatiite (Poidevin 1994; Piercey et al. 2001; Polat et al. 2002; Smithies 2002; Srivastava 2006; Chalapathi Rao and Srivastava 2009). The very low values of $\mathrm{Nb} / \mathrm{La}(0.15-0.22), \mathrm{Nb} / \mathrm{Ce}(0.07-0.08) \mathrm{Rb} / \mathrm{Sr}$ (0.01-0.05) and $\mathrm{Rb} / \mathrm{Ba}(0.04-0.07)$ showed by the present dyke also rule out the effects of postmagmatic deuteric alteration processes as well as crustal contamination (Lafleche et al. 1992; Mir et al. 2011). The negative Nb, Ta and Ti anomalies on multi-element diagram are common features in the Archaean as well as Phanerozoic boninites (Smithies et al. 2004) and also characteristic of the magmatism related to subduction (Wilson 1989; Condie 1997). The relative depletion in the HFSEs (Nb, Ta and $\mathrm{Ti}$ ) may have been affected by crustal contamination; however, these anomalies are consistent in the global boninitic rocks and it looks like much of these and the overall trace element signatures may have been largely inherited from the enriched sources (Cameron et al. 1983; Hall and Hughes 1990; Nielsen et al. 2002; Smithies 2002; Srivastava 2006). 


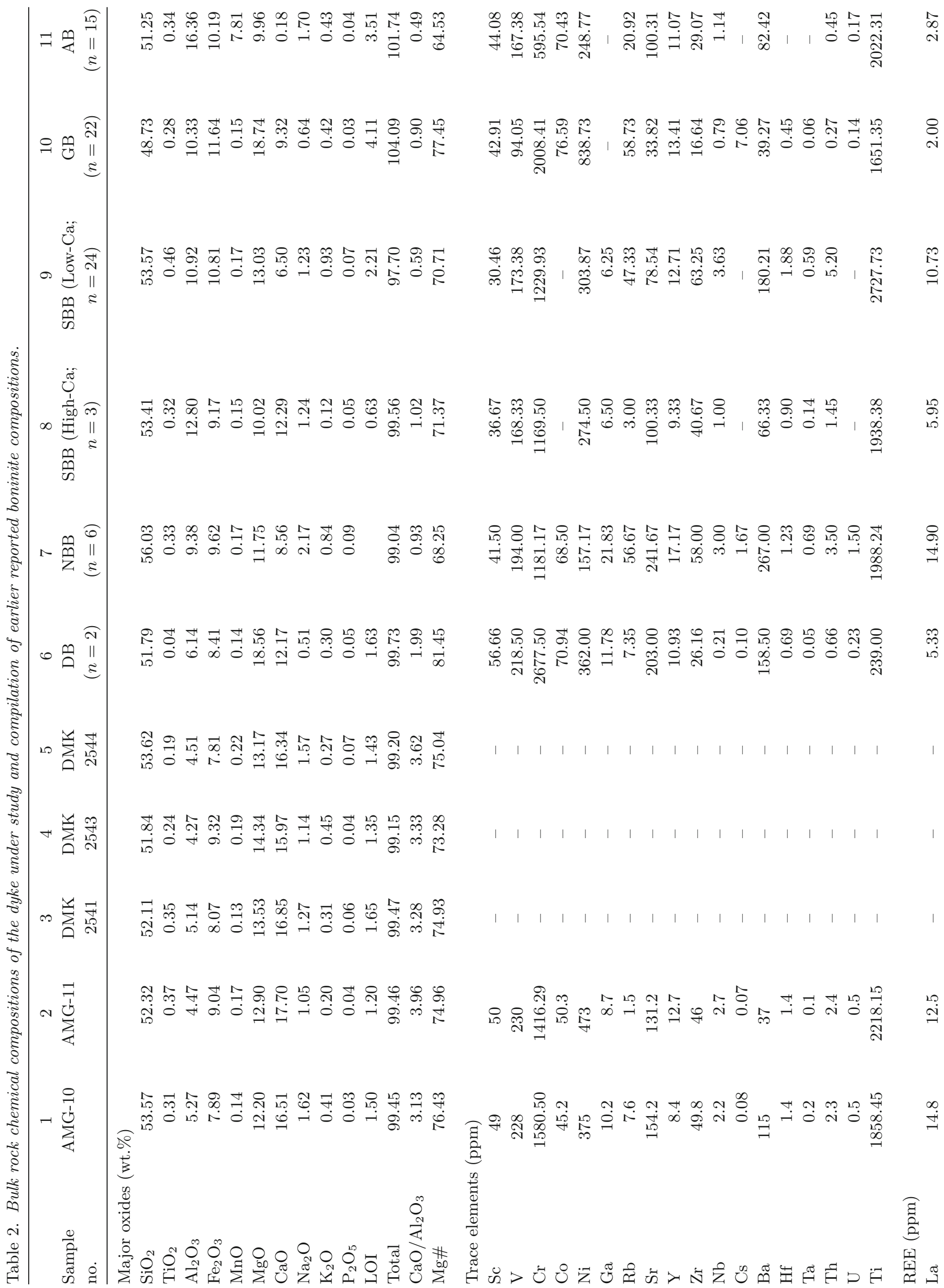




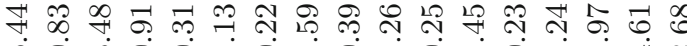

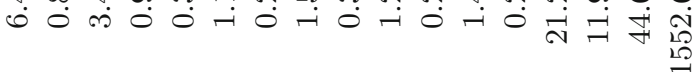

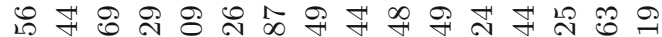

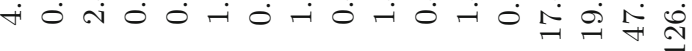

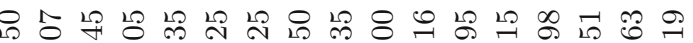

○

\& $\vec{\infty}$ సิ ก

๓ ลิ

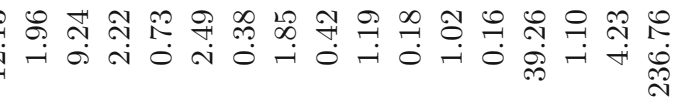

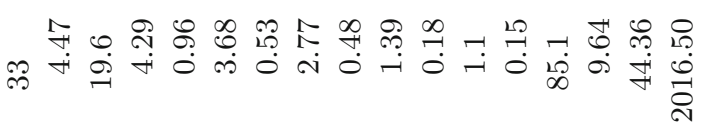

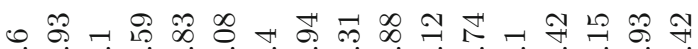
बे

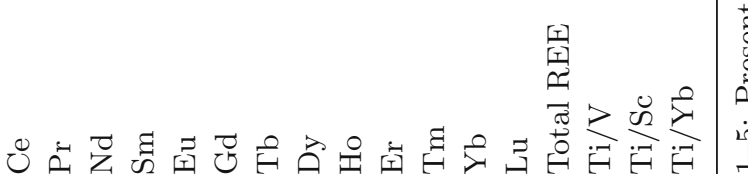

Global boninites have a marked U-shape (depleted middle REE (MREE) than the LREE and HREE) multi-element pattern (Bedard 1999; Polat et al. 2002; Manikyamba et al. 2005). Such a depleted MREE pattern is not observed in the present dyke and remains absent in the Bastar craton boninites. Whereas the depleted HREEs compared to LREE and MREE patterns are observed to be a characteristic feature of all the Bastar boninites (Subba Rao et al. 2008a; Chalapathi Rao and Srivastava 2009).

The $\mathrm{CaO}$ content of the present dyke is very high that it ranges from 15.9 to $17.7 \mathrm{wt} . \%$, which is higher compared to the Proterozoic boninites of the Bastar craton and Gadwal greenstone belt. The $\mathrm{Al}_{2} \mathrm{O}_{3}$ content of the dyke is very low; however, the lower $\mathrm{Al}_{2} \mathrm{O}_{3}$ and higher $\mathrm{CaO}$ are the characteristics of the nearby Dongargarh boninite from the same Bastar craton and considered here to be distinct features of these dykes. Very low $\mathrm{CaO}$ values (i.e., 0.10-0.12 wt.\%) are characteristics of the Archaean boninites (Smithies 2002). Based on the lower amounts of $\mathrm{Al}_{2} \mathrm{O}_{3}$ and higher $\mathrm{CaO} / \mathrm{Al}_{2} \mathrm{O}_{3}$ ratios, the present dyke is classified, more precisely, as a high-Ca boninite variety (figure 9). The phanerozoic boninites generally show a very high $\mathrm{Al}_{2} \mathrm{O}_{3} / \mathrm{TiO}_{2}$ ratio and in Archaean boninites such ratio varies from 26 to 88 . The value of $\mathrm{Al}_{2} \mathrm{O}_{3} / \mathrm{TiO}_{2}$ in the present dyke varies

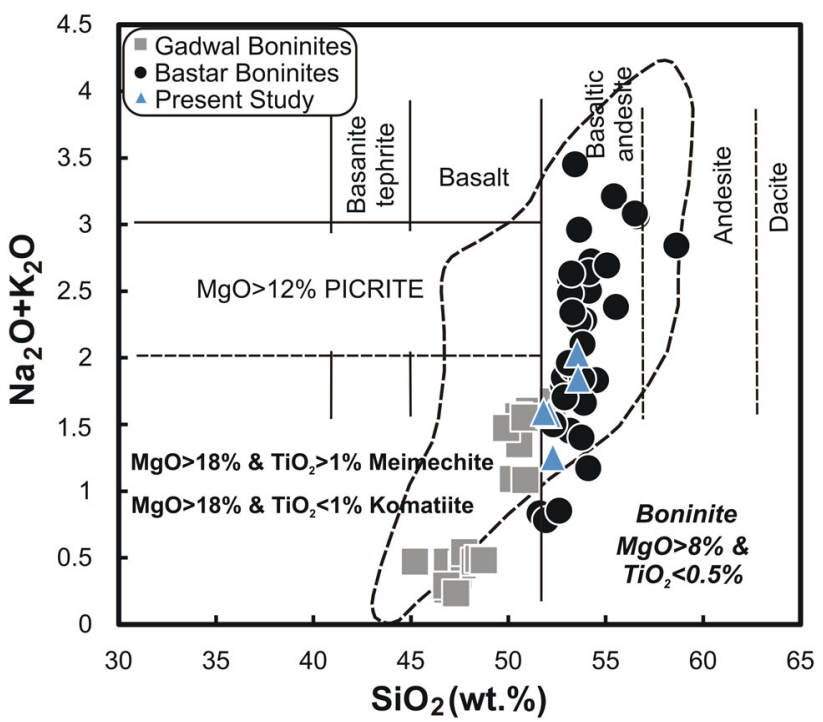

Figure 5. Total alkali silica (TAS) classification diagram (after Le Bas 2000) for high-Mg mafic dykes and compositional variation of present dyke is compared with the Archaean boninite field (Smithies et al. 2004), Bastar boninites (Srivastava 2006; Subba Rao et al. 2008a, b; Chalapathi Rao and Srivastava 2009) and Gadwal boninites (Manikyamba et al. 2005). 
from 12 to 24. The lower $\mathrm{Al}_{2} \mathrm{O}_{3} / \mathrm{TiO}_{2}$ values can be attributed to the lower content of $\mathrm{Al}_{2} \mathrm{O}_{3}$ in the present dyke, which is also a feature of Dongargarh boninite as mentioned earlier. On the other hand, $\mathrm{TiO}_{2}$ contents of the dyke are very low (0.190.37 wt.\%) and following the boninite classification where $\mathrm{TiO}_{2}$ is mostly $<0.5$ wt.\%. The bivariate plots, using $\mathrm{Zr} / \mathrm{Ti}, \mathrm{Ti} / \mathrm{V}, \mathrm{Ti} / \mathrm{Sc}$ and $\mathrm{Ti} / \mathrm{Yb}$ ratios (figure 10a-d) discriminating between Archaean boninites with contaminated komatiites and SHMB, show a distinct affinity of the studied samples towards the Archaean boninites.

Smithies et al. (2004) recognised two groups of Archaean high-Mg mafic rocks having strong refractory mantle source, e.g., Whundo type and Whitney type. Whundo type (known in age from 3.12 and $2.8 \mathrm{Ga}$ ) rocks are considered to be true Archaean analogues of modern boninites, having similarities in the composition and also their association with tholeiitic to calc-alkaline mafic to intermediate magmatism. They are similar to modern boninites in terms of their derivation from the metasomatised refractory mantle. On the other hand, Whitney type (of $3.8 \mathrm{Ga}$ ) rocks are closely associated with ultramafic komatiites and are considered to be derived by plume magmatism. Pearce et al. (1992) suggested the genesis of boninites by melting of depleted residual metasomatic MORB mantle where metasomatism is due to fluids and melts are derived from the dehydrated subducted slab. Earlier studies (e.g., Arndt et al. 1987; Sun et al. 1989) reported the role of assimilationfractional crystallisation (AFC) of komatiites for the formation of boninites. The present dyke represents a Whundo type of magmatism and is not consistent with a komatiite AFC model in its genesis because of no record of komatiite in the vicinity.

The formation of boninites by higher degrees of partial melting of a refractory mantle source related to the subduction is now well established (Tatsumi and Eggins 1995; Turner et al. 1997; Green and Falloon 1998; Falloon and Danyushevsky 2000; Kushiro 2007). Very low contents of titanium are considered to be due to residual Tibearing phase after melting (Green and Pearson 1986) in the refractory mantle source formed by the tholeiitic melt extraction (Sun and Nesbitt 1978). Subsequent enrichment of refractory mantle source regions and higher concentrations of LILEs, Th and La compared to HFSEs are considered to be the result of interaction with subduction-derived fluid prior to the second-stage melting (Sun and Nesbitt 1978; Hickey and Frey 1982; Crawford et al. 1989; Falloon and Danyushevsky 2000; Polat et al. 2002; Smithies et al. 2004).
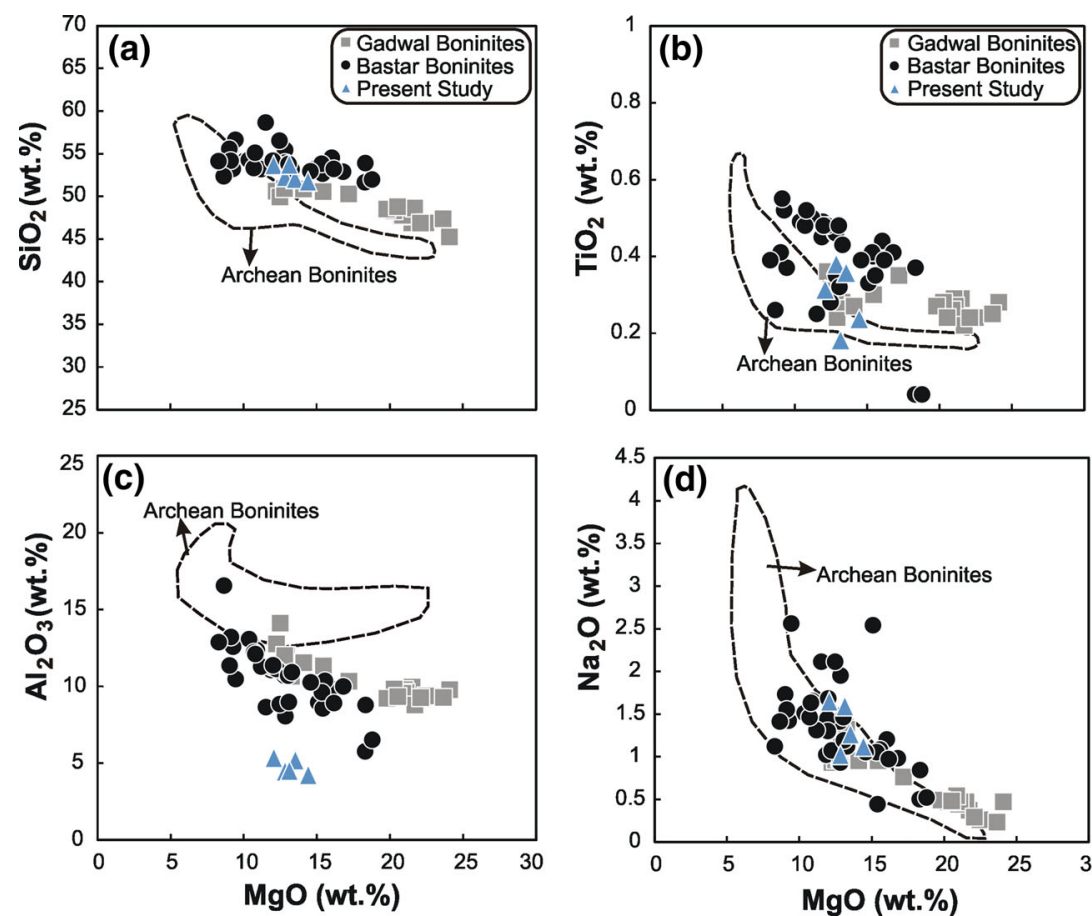

Figure 6. (a-d) Variations of major oxides $\left(\mathrm{SiO}_{2}, \mathrm{TiO}_{2}, \mathrm{Al}_{2} \mathrm{O}_{3}\right.$ and $\left.\mathrm{Na}_{2} \mathrm{O}\right)$ with $\mathrm{MgO}$ (wt.\%) and are compared with earlier reported Archaean boninites (Smithies et al. 2004), Bastar boninites (Srivastava 2006; Subba Rao et al. 2008a, b; Chalapathi Rao and Srivastava 2009) and Gadwal boninites (Manikyamba et al. 2005). 

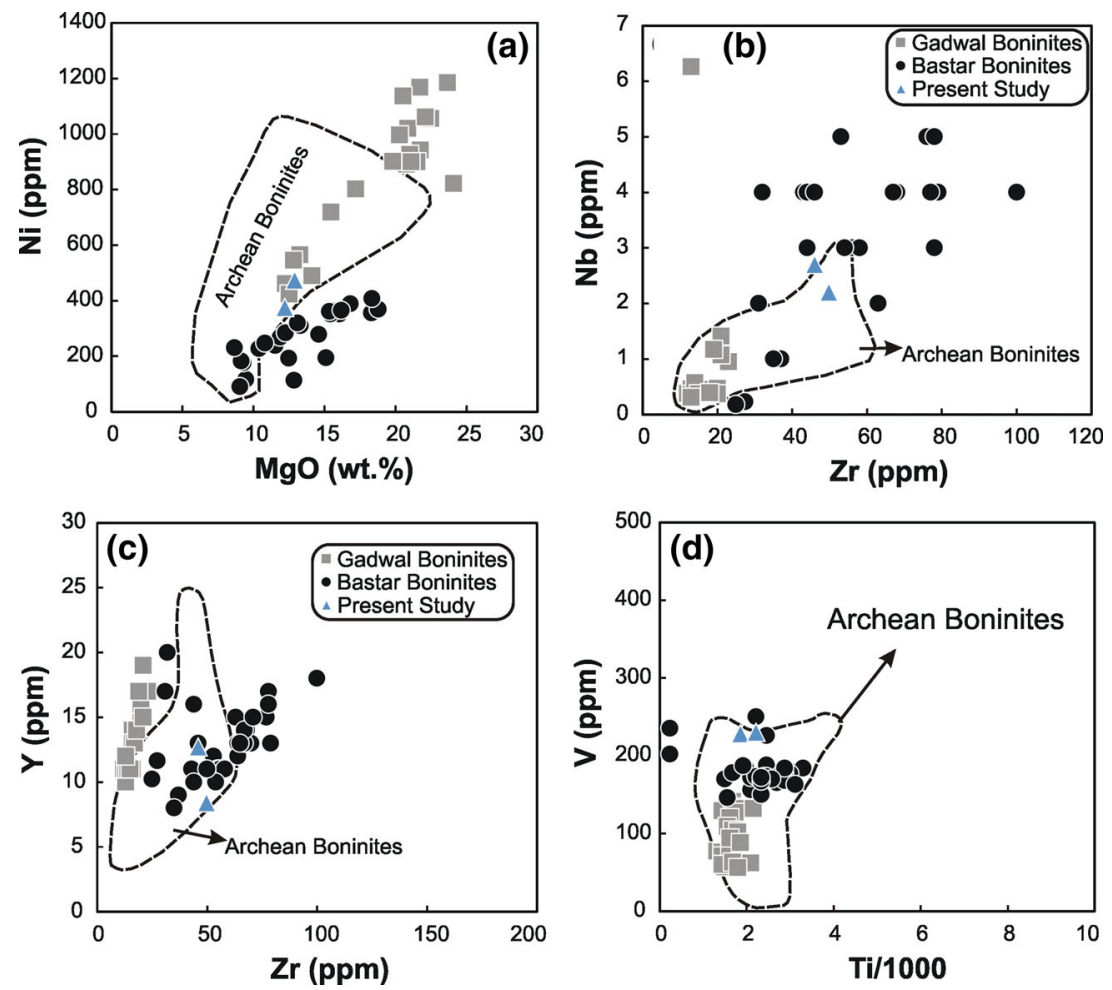

Figure 7. (a) $\mathrm{MgO}$ (wt.\%) vs. Ni (ppm); (b) Zr (ppm) vs. Nb (ppm); (c) Zr (ppm) vs. Y (ppm); and (d) Ti/1000 vs. $\mathrm{V}(\mathrm{ppm})$ variation diagrams for the present boninite dyke and their comparison with earlier reported Archaean boninites (Smithies et al. 2004), Bastar boninites (Srivastava 2006; Subba Rao et al. 2008a, b; Chalapathi Rao and Srivastava 2009) and Gadwal boninites (Manikyamba et al. 2005).

The formation of boninitic dykes from a refractory mantle source and subduction-induced metasomatism have been known from the Bastar craton (Srivastava 2008; Chalapathi Rao and Srivastava 2009) and the neighbouring Singhbhum craton (Mir et al. 2015). It was suggested that the extensive extraction of tholeiitic melt during Archaean to Palaeoproterozoic (Srivastava and Gautam 2009) may have resulted in the formation of refractory mantle sources beneath the Bastar craton and the subduction-related tectonic settings (Yedekar et al. 1990; Asthana et al. 2016) could be the reason for geochemical characteristics typical of boninite shown by these rocks.

The samples under the study show very low $\mathrm{TiO}_{2}$ contents (i.e., $<0.40$ wt.\%) with correspondingly higher $\mathrm{CaO} / \mathrm{TiO}_{2}$ ratios (47.84-86.00) indicate their highly refractory mantle source which had experienced earlier the tholeiitic melt extraction event. The enriched Ce/Ta ratios (158-330) along with negative HFSE anomalies reflect the contribution of subduction-related component in the melt (Smellie et al. 1995) and thus support the role of subduction in influencing the geochemical characters of the present boninite dyke in the western part of the Bastar craton.

\subsection{Geodynamics involved}

Boninite dyke emplaced in the Archaean basement was reported from the margin of the Chhattisgarh basin in the northern Bastar craton (Subba Rao et al. 2008a, b). This dyke inferred to form in intra-cratonic settings, similar to other Archaean boninite rocks reported from other parts of the world (e.g., Smithies 2002). Boninite dyke reported from the Neoarchean-Palaeoproterozoic Dongargarh Supergroup is intrusive into the Bijli rhyolites in northwestern Bastar craton (Chalapathi Rao and Srivastava 2009) and is considered to represent a fossil subduction zone where a lithospheric mantle in this domain appears to have retained memories of ancient subduction. Palaeoproterozoic boninites are reported from the southern Bastar craton which are intrusives into basement gneisses (Srivastava and Singh 2003; Srivastava et al. 2004, 2011) and also from the areas of Bastanar, Dantewada and Katekalyan of southern Bastar craton 

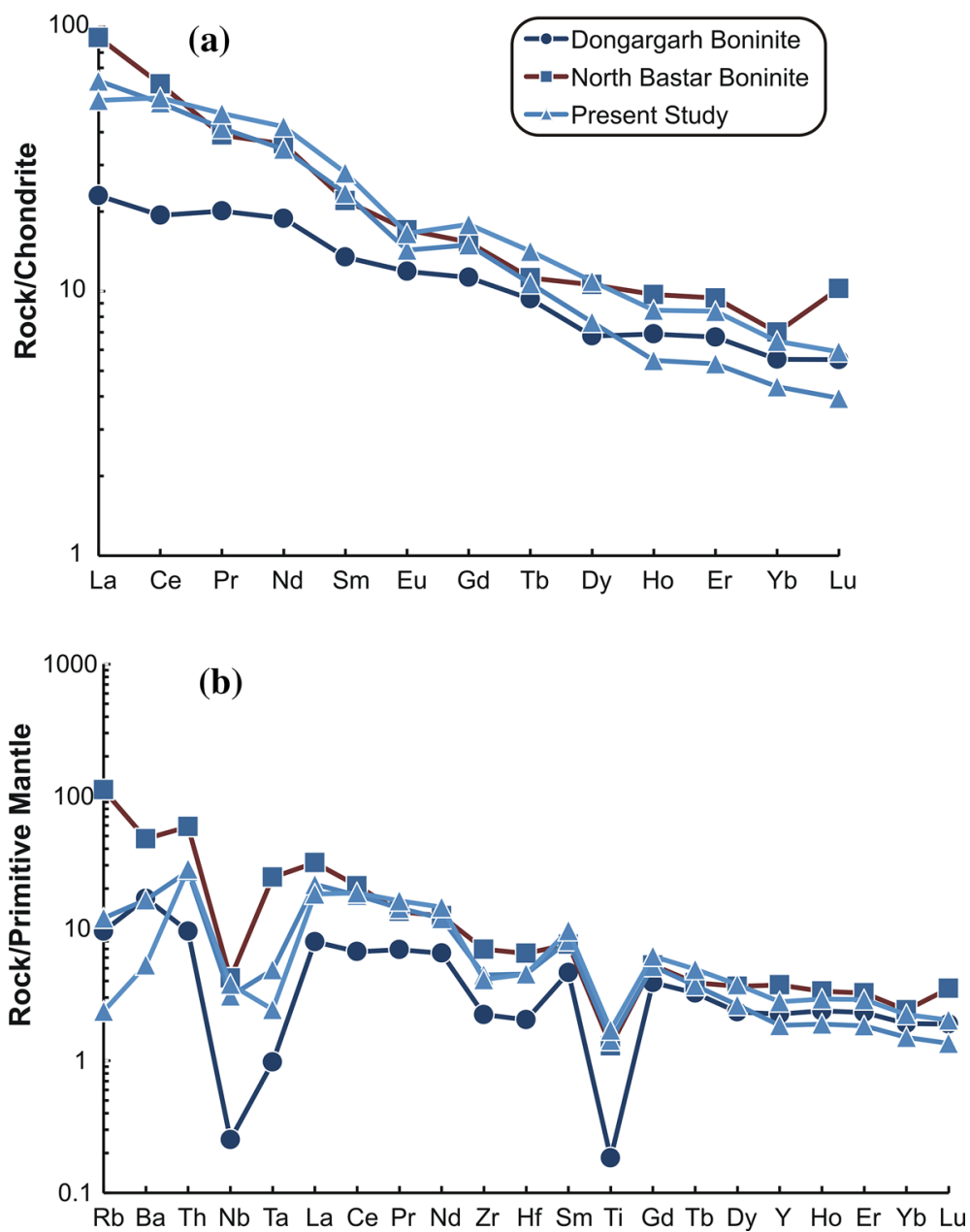

Figure 8. (a) Chondrite-normalised (after Sun and McDonough 1989) and (b) primitive-mantle normalised (after Sun and McDonough 1989) patterns for the present study dyke and boninite dykes from the north Bastar craton (Subba Rao et al. 2008a, b) and Dongargarh boninite dyke (Chalapathi Rao and Srivastava 2009).

(Srivastava 2006) where they are very well exposed. These dykes are also reported to form in an intracratonic setting. This clearly indicates the presence of widespread intra-cratonic boninite magmatism in the whole Bastar craton during Neoarchean to Palaeoproterozoic.

A number of geodynamic models have been proposed for the evolution of central Indian Neoarchean-Palaeoproterozoic Dongargarh Supergroup rocks (e.g., Yedekar et al. 1990; Raza et al. 1993; Neogi et al. 1996; Asthana et al. 1996, 1997, 2016, 2017; Manikyamba et al. 2016). Yedekar et al. (1990) envisaged the Dongargarh volcanic rocks as remnant island arc lavas and proposed a southward subduction model of the Bundelkhand proto-continent under the Deccan proto-continent during the Proterozoic. Raza et al. (1993) also supported the subduction-related origin of the Dongargarh volcanics that exist along a Palaeoproterozoic ocean closure in central India and mark the suture of two proto-continental masses. Asthana et al. (1996, 1997) suggested an arc-related setting for Khairagarh volcanics of the Dongargarh Supergroup, which are inter-layered with terrigenous sediments formed in back-arc basin. In recent works, Asthana et al. $(2016,2017)$ proposed a ridge subduction model followed by slab window along Palaeoproterozoic central Indian suture to account for the distribution of fore arc-arc-back arc association of the Bastar craton. Geochemical studies on gneisses and granitoids also provide significant evidence for the multiphase subduction-related events and for crustal growth during Proterozoic and Archaean in the Bastar craton (Hussain et al. 2004; Mondal et al. 2006). Therefore, the convergence-related evolution of the Bastar craton and especially the Dongargarh Supergroup is clearly established from the previous studies.

The present boninite dyke is intrusive into the Amgaon gneisses and not in the Dongargarh 


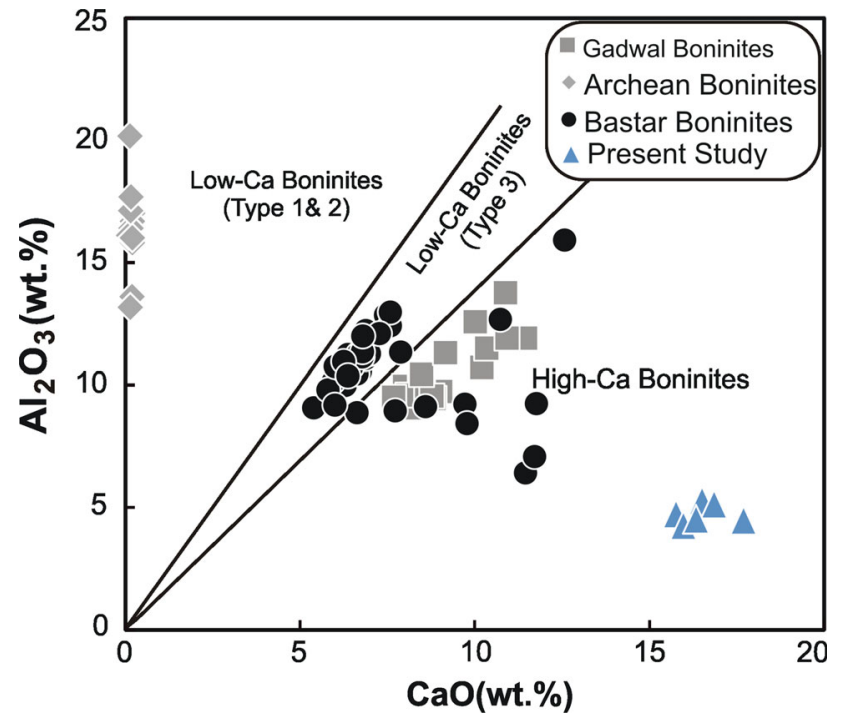

Figure 9. $\mathrm{CaO} / \mathrm{Al}_{2} \mathrm{O}_{3}$ classification for boninites (Crawford et al. 1989). Boninite compositions from earlier reports such as Archaean boninite field (Smithies et al. 2004), Bastar boninites (Srivastava 2006; Subba Rao et al. 2008a, b; Chalapathi Rao and Srivastava 2009) and Gadwal boninites (Manikyamba et al. 2005) are also given for comparison.
Supergroup rocks unlike the Dongargarh boninite reported by Chalapathi Rao and Srivastava (2009). The Amgaon gneisses of the western Bastar craton shows widespread ages of 2.5-2.6 Ga (Ramakrishnan and Vaidyanadhan 2008) and forms the basement for the Dongargarh Supergroup rocks (Sarkar et al. 1994). The rocks belonging to Dongargarh volcano-sedimentary successions are exposed to 40 $50 \mathrm{~km}$ south of the present boninite dyke. Although both the dykes are intruded in different lithological units but their proximity may indicate that both the dykes are younger than the 2.142.18 Ga Bijli rhyolites (Sarkar et al. 1994; Divakara Rao et al. 2000) but older than the $1.86 \mathrm{Ga}$ dyke swarm of the Bastar (Srivastava 2006). The southern Bastar boninites are also reported to be emplaced at $2118 \pm 2 \mathrm{Ma}$ (Srivastava et al. 2011). The analogous mineralogical and geochemical characteristics of the present dyke with the rest of the Bastar boninites may indicate similar mantle source regions for their genesis and thus
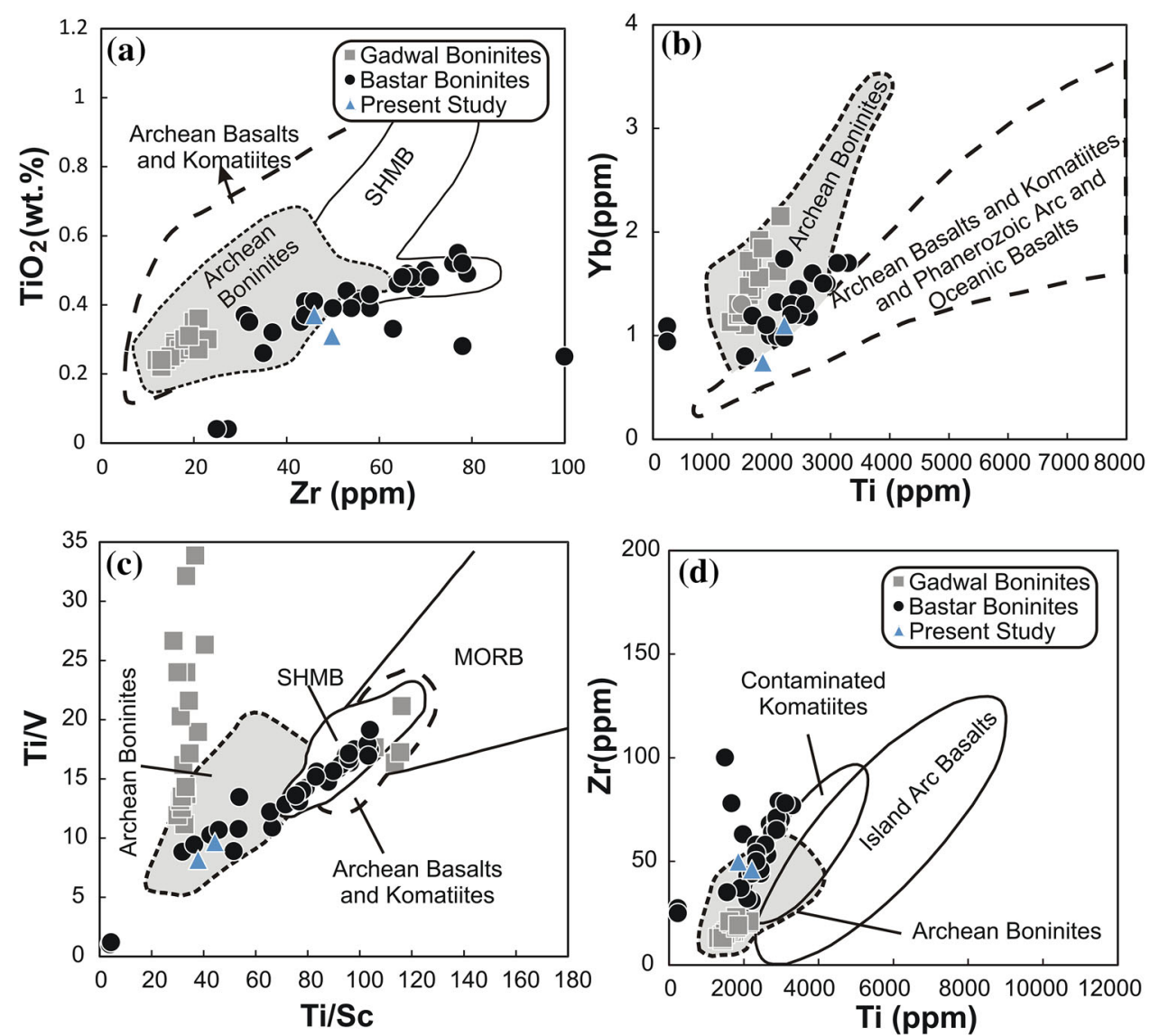

Figure 10. (a) $\mathrm{Zr}(\mathrm{ppm})$ vs. $\mathrm{TiO}_{2}$ (wt.\%), (b) $\mathrm{Ti}(\mathrm{ppm})$ vs. $\mathrm{Yb}(\mathrm{ppm})$, (c) Ti/Sc vs. Ti/V, and (d) $\mathrm{Ti}$ (ppm) vs. Zr (ppm) variation diagram for the present boninite dyke and their comparison with Archaean boninites, Gadwal boninites, Bastar boninites, SHMB, Archaean basalts and komatiites, Phanerozoic arc and oceanic basalts and MORB. Data from Poidevin (1994), Smithies (2002), Polat et al. (2002), Smithies et al. (2004), Manikyamba et al. (2005), Subba Rao et al. (2008a, b) and Chalapathi Rao and Srivastava (2009). 
represent a widespread boninite intrusion event in the Bastar craton during the Palaeoproterozoic. The significant geochemical characteristics corresponding with subduction setting also suggest that like the Dongargarh boninite, the present dyke (along with north Bastar boninite) represents the preservation of ancient subduction-related signatures retained by the lithospheric mantle of this domain during the evolution of the Bastar craton and Dongargarh Supergroup.

\section{Conclusions}

The boninite dyke under study shows the presence of mafic minerals such as pyroxenes and amphiboles along with subordinate amounts of plagioclase. The pyroxenes are mostly diopside in composition $\left(\mathrm{Wo}_{48-50}\right)$, whereas amphiboles show the composition of actinolite and hornblende. It shows enrichment of LILEs along with depletion of HFSEs (Nb, Ti), and based on low $\mathrm{TiO}_{2}(0.19$ 0.37 wt.\%), higher $\mathrm{CaO} / \mathrm{Al}_{2} \mathrm{O}_{3}(3.13-3.96)$ it is classified as high $\mathrm{Ca}$ boninite. These specific geochemical characteristics are consistent with the refractory mantle source formed by the extraction of basaltic magma during Archaean/Early Proterozoic times in the Bastar craton. The similarity of the present dyke with the earlier reported Bastar boninites and particularly with north Bastar boninite indicates the similar composition of the mantle source and a widespread Palaeoproterozoic boninitic event in the craton. This boninite magmatism indicates the presence of remnant subduction-related signatures in the lithospheric mantle formed during the evolution of the Bastar craton.

\section{Acknowledgements}

We thank the two anonymous reviewers and Associate Editor R Bhutani for their constructive comments and suggestions. $\mathrm{BH}$ and $\mathrm{DM}$ are gratefull to the Council of Scientific \& Industrial Research (CSIR), New Delhi and UGC-SAP-DRS for the financial assistance. AD is thankful to the Head of the Geology Department, SPPU, for the support.

\section{References}

Arndt N T, Brügmann G E, Lenhert K, Chappel B W and Chauvel C 1987 Geochemistry, petrogenesis and tectonic environment of Circum-Superior Belt basalts, Canada; In: Geochemistry and Mineralisation of Proterozoic Volcanic Suites (eds) Pharaoh T C, Beckinsdale R D and Rickard D, Blackwell, London.

Asthana D, Dash M R, Pophare A M and Khare S K 1996 Interstratified low-Ti and high-Ti volcanics in the arcrelated Khairagarh Group of central India; Curr. Sci. $\mathbf{7 1}$ 304-306.

Asthana D, Khare S K, Pophare A M and Dash M R 1997 Comments on - Geochemistry of the Dongargarh volcanic rocks, central India: Implications for the Precambrian mantle; Precamb. Res. 84 105-107.

Asthana D, Kumar H, Balakrishnan S, Xia Q and Feng M 2016 An early cretaceous analogue of the $\sim 2.5$ Ga Malanjkhand porphyry $\mathrm{Cu}$ deposit, central India; Ore. Geol. Rev. 72 1197-1212.

Asthana D, Kumar S, Vind A K, Zehra F, Kumar H and Pophare A M 2017 Geochemical fingerprinting of $\sim 2.5 \mathrm{Ga}$ forearc-arc-backarc related magmatic suites in the Bastar craton, central India; J. Asian Earth Sci., https://doi. org/10.1016/j.jseaes.2017.10.006.

Beccaluva L and Serri G 1988 Boninitic and low-Ti subduction-related lavas from intraoceanic arc-backarc systems and low-Ti ophiolites: A reappraisal of their petrogenesis and original tectonic setting; Tectonophys. 146 291-315.

Bedard J H 1999 Petrogenesis of Boninites from the Betts Cove Ophiolite, Newfoundland, Canada: Identification of subducted source components; J. Petrol. 40(12) 18531889.

Cameron W E, McCulloch M T and Walker D A 1983 Boninite petrogenesis: Chemical and $\mathrm{Nd}-\mathrm{Sr}$ isotopic constraints; Earth Planet. Sci. Lett. 65 75-89.

Chalapathi Rao N V and Srivastava R K 2009 A new find of boninite dyke from the Paleoproterozoic Dongargarh Supergroup: Inference for a fossil subduction zone in the Archean of the Bastar craton, central India; J. Mineral. Geochem. 186(3) 271-282.

Chaudhuri A K, Saha D, Deb G K, Deb S P, Mukherjee M K and Ghosh G 2002 The Purana basins of southern cratonic provinces of India a case for Mesoproterozoic fossil rifts; Gondwana Res. 5 23-33.

Condie K C 1997 Sources of Proterozoic mafic dyke swarms: Constraints from Th/Ta and La/Yb ratios; Precamb. Res. $813-14$.

Crawford A J, Falloon T J and Green D H 1989 Classification, petrogenesis and tectonic setting of boninites; In: Boninites and Related Rocks (ed.) Crawford A J, Unwin Hyman, London, pp. 1-49.

Crookshank H 1963 Geology of southern Bastar and Jeypore from the Bailadila range to the Eastern Ghats; Geol. Surv. India Memoir $\mathbf{8 7} 150$.

Das P, Das K, Chakraborty P P and Balakrishnan S 2011 1420 Ma diabasic intrusives from the Mesoproterozoic Singhora Group, Chhattisgarh Supergroup, India: Implications towards non-plume intrusive activity; J. Earth Syst. Sci. 120 223-236.

Divakara Rao V, Narayana B L, Rama Rao P, Murthy N $\mathrm{N}$, Subba Rao M V, Mallikharjuna Rao J and Reddy G L N 2000 Precambrian acid volcanism in central India - Geochemistry and origin; Gondwana Res. 3 215226 . 
Falloon T J and Danyushevsky L V 2000 Melting of refractory mantle at 1.5, 2 and $2.5 \mathrm{GPa}$ under anhydrous and $\mathrm{H}_{2} \mathrm{O}$ undersaturated conditions: Implications for the petrogenesis of high-Ca boninites and the influence of subduction components on mantle melting; J. Petrol. 41 $257-283$.

Falloon T J, Danyushevsky L V, Crawford T J, Maas R, Woodhead J D, Eggins S M, Bloomer S H, Wright D J, Zlobin S K and Stacey A R 2007 Multiple mantle plume components involved in the petrogenesis of subduction-related lavas from the northern termination of the Tonga Arc and northern Lau Basin: Evidence from the geochemistry of arc and backarc submarine volcanics; Geochem. Geophys. Geosyst., https://doi.org/10. 1029/2007GC001619.

Falloon T J, Danyushevsky L V, Crawford A J, Meffre S, Woodhead J D and Bloomer S H 2008 Boninites and Adakites from the northern termination of the Tonga Trench: Implications for Adakite Petrogenesis; J. Petrol. $49697-715$.

French J E, Heaman L M, Chacko T and Srivastava R K 2008 1891-1883 Ma Southern Bastar-Cuddapah mafic igneous events, India: A newly recognized large igneous province; Precamb. Res. 160 308-322.

Ganguly S, Manikyamba C, Saha A, Lingadevaru M, Santosh M, Rambabu S, Khelen A C, Purushottam D and Linga D 2016 Geochemical characteristics of gold bearing boninites and banded iron formations from Shimoga greenstone belt, India: Implications for gold genesis and hydrothermal processes in diverse tectonic settings; Ore. Geol. Rev. 73 82-89.

Gautam G C and Srivastava R K 2011 Petrology, geochemistry and petrogenesis of Early Precambrian mafic dyke swarm from Dondi-Bhanupratappur-Keshkal, Central Bastar craton, India; In: Dyke Swarms: Keys for Geodynamic Interpretation (ed.) Srivastava R K, SpringerVerlag, Heidelberg, pp. 203-218.

Green D H and Falloon T J 1998 Pyrolite: A Ringwood concept and its current expression; In: The Earth's Mantle: Composition, Structure and Evolution (ed.) Jackson I, Cambridge University Press, Cambridge, pp. 311378.

Green T H and Pearson N J 1986 Ti-rich accessory phase saturation in hydrous mafic-felsic compositions at high P-T; Chem. Geol. 54 185-201.

Hall R P and Hughes D J 1990 Precambrian mafic dykes of southern Greenland; In: Mafic Dykes and Emplacement Mechanisms (eds) Parker A J, Rickwood D H, Tucker D $\mathrm{H}$ and Balkema A A, Rotterdam, pp. 481-495.

Hickey R L and Frey F A 1982 Geochemical characteristics of boninitic series volcanics: Implications for their source; Geochim. Cosmochim. Acta 46 2099-2115.

Hussain F, Mondal M E A and Ahmad T 2004 Geodynamic evolution and crustal growth of the central Indian shield: Evidence from geochemistry of gneisses and granitoids; $J$. Earth Syst. Sci. 113 699-714.

Hussain M F, Ahmad T and Mondal M E A 2008 Geochemistry of the Precambrian MAFIC DYKE SWARMS of the central and northeastern parts of Bastar Craton, central India: Constraints on their enrichment processes; In: Indian Dykes: Geochemistry, Geophysics and Geochronology (eds) Srivastava R K, Sivaji C and Chalapathi Rao
N V, Narosa Publishing House Pvt. Ltd., New Delhi, pp. 397-412.

Krishnamurthy P, Chaki A, Pandey B K, Chimote J S and Singh S N 1988 Geochronology of the granite-rhyolite suite of the Dongargarh Supergroup, central India; In: Fourth National Symposium on Mass Spectrometry, Indian Institute of Science, Bangalore, EPS-2/1-3.

Krishnamurthy P, Sinha D K, Rai A K, Seth D K and Singh S N 1990 Magmatic rocks of the Dongargarh supergroup, central India - Their petrological evolution and implications on metallogeny; Geol. Surv. India Spec. Publ. 28 303-319.

Kushiro I 2007 Origin of magmas in subduction zones: A review of experimental studies; Proc. Jpn. Acad. Ser. $\mathbf{8 3}$ $1-15$.

Lafleche M R, Dupuy C and Bougault H 1992 Geochemistry and petrogenesis of Archean volcanic rocks of the southern Abitibi Belt, Quebec; Precamb. Res. 57 207-241.

Leake B E, Woolley A R, Arps C E S, Birch W D, Gilbert M C, Grice J D, Hawthorne F C, Kato A, Kisch H J, Krivovichev V G, Linthout K, Laird J, Mandarino J A, Maresch W V, Nickel E H, Rock N M S, Schumacher J C, Smith D C, Stephenson N C N, Ungaretti L, Whittaker E J W and Youzhi G 1997 Nomenclature of amphiboles: Report of the subcommittee on amphiboles of the international mineralogical association, commission on new minerals and mineral names; Am. Mineral. 82 1019-1037.

Le Bas M J 2000 IUGS reclassification of the high-Mg and picritic volcanic rocks; J. Petrol. 41 1467-1470.

Manikyamba C, Naqvi S M, Subba Rao D V, Ram Mohan M, Khanna T C, Rao T G and Reddy G 2005 Boninites from the Neoarchaean Gadwal greenstone belt, Eastern Dharwar craton, India: Implications for Archaean subduction processes; Earth Planet. Sci. Lett. 23 65-83.

Manikyamba C, Santosh M, Chandan Kumar B, Rambabu S, Tang L, Saha A, Khelen A, Ganguly S, Singh T D and Subba Rao D V 2016 Zircon U-Pb geochronology, Lu-Hf isotope systematic, and geochemistry of bimodal volcanic rocks and associated granitoids from Kotri belt, central India: Implications for Neoarchean-Paleoproterozoic crustal growth; Gondwana Res. 38 313-333.

Meffre S, Falloon T J, Crawford T J, Hoernle K, Hauff F, Duncan R A, Bloomer S H and Wright D J 2012 Basalts erupted along the Tongan fore arc during subduction initiation: Evidence from geochronology of dredged rocks from the Tonga fore arc and trench; Geochem. Geophys. Geosys., https://doi.org/10.1029/2012GC004335.

Melluso L and Sethna S F 2011 Mineral compositions of the Deccan igneous rocks of India: An overview; In: Topics in Igneous Petrology (eds) Ray J, Sen G and Ghosh B, Springer Science.

Merlet C 1994 An accurate computer correction program for quantitative electron probe microanalysis; Microchim. Acta 114/115 363-376.

Mir A R, Alvi S H and Balaram V 2011 Geochemistry of the mafic dykes in parts of the Singhbhum Granitoid complex: Petrogenesis and tectonic setting; Arab. J. Geosci. 4933 943.

Mir A M, Alvi S H and Balaram V 2015 Boninitic geochemical characteristics of high-Mg mafic dykes from the Singhbhum granitoid complex, Eastern India; Chin. J. Geochem. 34(2) 241-251. 
Mondal M E A, Hussain M F and Ahmad T 2006 Continental growth of Bastar craton, central Indian shield during precambrian via multiphase subduction and lithospheric extension/rifting: Evidence from geochemistry of gneisses, granitoids and mafic dykes; J. Geosci. $49137-$ 151.

Mondal M E A, Hussain M F and Ahmad T 2007 Geochemistry and petrogenesis of the Proterozoic mafic dyke swarms of Bastar craton of central Indian Shield; J. Appl. Geochem. 9 17-27.

Naqvi S M and Rogers J J W 1987 Precambrian geology of India; Oxford University Press, Oxford, 233p.

Neogi S, Miura H and Hariya Y 1996 Geochemistry of the Dongargarh volcanic rocks, central India: Implications for the Precambrian mantle; Precamb. Res. 76 77-91.

Nielsen S G, Joel A B and Krogstad E J 2002 Petrogenesis of an early Archaean (3.4 Ga) norite dyke, Isua, West Greenland: Evidence for early Archaean crustal recycling; Precamb. Res. 118 133-148.

Pearce J A, van der Laan S R, Arculus R J, Murton B J, Ishii T, Peate D W and Parkinson I J 1992 Boninite and harzburgite from Leg 125 (Bonin-Mariana forearc): A case study of magma genesis during the initial stages of subduction; In: Proceedings of the Ocean Drilling Program, Scientific Results, 125 pp. 623-659.

Piercey S J, Murphy D C, Mortensen J K and Paradis S 2001 Boninite magmatism in a continental margin setting, Yukon-Tanana terrane, southeastern Yukon, Canada; Geology 29 731-734.

Pisarevsky S A, Biswal T K, Wang X-C, De Waele B, Ernst R, Söderlund U, Tait J A, Ratre K, Singh Y K and Cleve M 2013 Palaeomagnetic, geochronological and geochemical study of Mesoproterozoic Lakhna Dykes in the Bastar Craton, India: Implications for the Mesoproterozoic supercontinent; Lithos 174 125-143.

Poidevin J L 1994 Boninite-like rocks from the Paleoproterozoic greenstone belt of Bogoin, Central African Republic: Geochemistry and petrogenesis; Precamb. Res. 68 97-113.

Polat A, Hofmann A W and Rosing M 2002 Boninite-like volcanic rocks in the 3.7-3.8 Ga Isua greenstone belt, West Greenland: Geochemical evidence for intra-oceanic subduction zone processes in the early Earth; Chem. Geol. $184231-254$.

Ramachandra H M, Mishra V P and Deshmukh S S 1995 Mafic Dykes in Bastar Precambrian: Study of the Bhanupratappur-Keshkal Mafic Dyke Swarms; Geol. Soc. India Mem. 33 183-208.

Ramakrishnan M 1990 Crustal development in southern Bastar, central India craton; Geol. Surv. India Spec. Publ. 28 44-66.

Ramakrishnan M and Vaidyanadhan R 2008 Geology of India; Geol. Soc. India 1556.

Rao G V 1981 The correlation of the Dongargarh, Chilpi and Sausar Groups. Geol. Surv. India Spec. Publ. 3 9-15.

Ratre K, De Waele B, Biswal T K and Sinha S 2010 SHRIMP geochronology for the 1450 Ma Lakhna dyke swarm: Its implication for the presence of Eoarchaean crust in the Bastar Craton and 1450-517 Ma depositional age for Purana basin (Khariar), Eastern Indian Peninsula; $J$. Asian Earth Sci. 39 565-577.

Raza M, Jafri S H, Alvi S H and Khan M S 1993 Geodynamic evolution of the Indian shield during Proterozoic:
Geochemical evidence from mafic volcanic rocks; J. Geol. Soc. India 41 455-469.

Roy A, Ramachandra H M and Bandopadhyay B K 2000 Supracrustal belts and their significance in the crustal evolution of central India; Geol. Surv. India Spec. Publ. 55 361-380.

Sarkar S N 1994 Chronostratigraphy and tectonics of the Dongargarh Supergroup Precambrian rocks in BhandaraDurg region, central India; Indian J. Earth Sci. 21 19-31.

Sarkar S N, Gopalan K and Trivedi J R 1981 New data on the geochronology of the Precambrians of Bhandara-Durg, central India; Indian J. Earth Sci. 8(2) 131-151.

Sarkar G, Gupta S N and Bishui P K 1994 New Rb-Sr isotopic age and geochemistry of granite gneisses from southern Bastar craton: Implication for crustal evolution; Indian Mineral. 48 7-12.

Sensarma S, Palme H and Mukhopadhyay D 2002 Crustmantle interaction in the genesis of siliceous high magnesian basalts: Evidence from the early Proterozoic Dongargarh Supergroup, India; Chem. Geol. 187 21-37.

Sinha D K, Jain S K and Naganath K P 2011 Tectonic significance and age of doleritic sill near Bandhalimal in the Singhora Protobasin of Chhattisgarh Basin, central India. In: Dyke Swarms: Keys for Geodynamic Interpretation (ed.) Srivastava R K, Springer-Verlag, Heidelberg, pp. $167-187$.

Smellie J L, Stone P and Evans J 1995 Petrogenesis of boninites in Ordovician Ballantrae complex Ophiolite, south western Scotland; J. Volcano. Geotherm. Res. 69 323-342.

Smithies R H 2002 Archaean boninite-like rocks in an intracratonic setting; Earth Planet. Sci. Lett. 197 19-34.

Smithies R H, Champion D C and Sun S S 2004 The case of Archaean boninites; Contrib. Mineral. Petrol. 147 705721.

Srivastava R K 2006 Geochemistry and petrogenesis of Neoarchaean high-Mg low-Ti mafic igneous rocks in an intracratonic setting, central India craton: Evidence for Boninite magmatism; Geochem. J. 40 15-31.

Srivastava R K 2008 Global intracratonic boninite-norite magmatism during the Neoarchean-Paleoproterozoic: Evidence from the central Indian Bastar craton; Int. Geol. Rev. 50 61-74.

Srivastava R K and Gautam G C 2008 Precambrian mafic dyke swarms from the southern Bastar central India craton: Present and future perspectives. In: Indian dykes: Geochemistry, geophysics and geochronology (eds) Srivastava R K, Sivaji C and Chalapathi Rao N V, Narosa Publishing House Pvt. Ltd., New Delhi, pp. 367-376.

Srivastava R K and Gautam G C 2009 Precambrian mafic magmatism in the Bastar craton, central India; J. Geol. Soc. India 73 52-72.

Srivastava R K and Gautam G C 2012 Early Precambrian mafic dyke swarms from the Central Archaean Bastar craton, India: Geochemistry, petrogenesis and tectonic implications; Geol. J. 47 144-160.

Srivastava R K and Gautam G C 2015 Geochemistry and petrogenesis of Paleo-Mesoproterozoic mafic dyke swarms from northern baster Craton, central India: Geodynamic implication in reference to Columbia supercontinent; Gondwana Res. 28 1061-1078. 
Srivastava R K and Singh R K 2003 Geochemistry of high$\mathrm{Mg}$ mafic dykes from the Bastar craton: Evidence of Late Archaean boninite-like rocks in an intracratonic setting; Curr. Sci. 85 808-812.

Srivastava R K and Singh R K 2004 Trace element geochemistry and genesis of the Precambrian sub-alkaline mafic dykes from central India craton: Evidence for mantle metasomatism; J. Asian Earth Sci. 23 373-389.

Srivastava R K, Singh R K and Verma S P 2004 Late Archaean mafic volcanic rocks from the southern Bastar greenstone belt, central India: Petrological and tectonic significance; Precamb. Res. 131 305-322.

Srivastava R K, Heaman L M, French J E and Ferreira Filho C F 2011 Evidence for a Paleoproterozic event of metamorphism in the Bastar craton, central India: P-T-t constraints from mineral chemistry and U-Pb geochronology of mafic dykes; Episodes 34(1) 13-24.

Stern R J and Bloomer S H 1992 Subduction zone infancy: Examples from the Eocene Izu-Bonin-Mariana and Jurassic California arcs; Geol. Soc. Am. Bull. 104(12) 16211636.

Subba Rao D V, Balaram V, Charan S N, Sridhar D N and Naqvi S M 2004 Proterozoic mafic dykes in and around Chattisgarh basin, central India: Inferences of compositional variation in mantle sources; DST-DCS News Lett. $141-5$.

Subba Rao D V, Sridhar D N, Balaram V, Nagaraju K, Rao T G, Keshavakrishna A and Singh U P 2008a Proterozoic mafic-ultramafic dyke swarms in the vicinity of Chattisgarh-Khariar-Singhora basins in Northern Bastar craton, central India; In: Indian Dykes: Geochemistry, Geophysics and Geochronology (eds) Srivastava R K, Sivaji C and Chalapathi Rao N V, Narosa Publishing House, New Delhi, pp. 377-396.

Corresponding editor: RAJNEESH BHUTANI
Subba Rao D V, Balaram V, Nagaraju K and Sridhar D N 2008b Palaeoproterozoic boninite like rocks in an intracratonic setting from Northern Bastar craton, central India; J. Geol. Soc. India 72 373-380.

Sun S S and McDonough W 1989 Chemical and isotopic systematics of oceanic basalts: Implications for mantle composition and processes; In: Magmatism in Ocean Basins (eds) Saunders A D and Norry M J, Geol. Soc. London Spec. Publ. 42 313-345.

Sun S S and Nesbitt R W 1978 Petrogenesis of Archaean ultrabasic and basic volcanism: Evidence from rare earth elements; Contrib. Mineral. Petrol. 65 301325.

Sun S S, Nesbitt R W and McCulloch M T 1989 Geochemistry and petrogenesis of Archaean and early Proterozoic siliceous high magnesian basalts. In: Boninites and Related Rocks (ed.) Crawford A J, Unwin Hyman, London, pp. 148-173.

Tatsumi Y and Eggins S 1995 Subduction Zone Magmatism; Blackwell Science, Oxford, 211p.

Turner S, Hawksworth G, Rogers N, Barlett J, Worthington T, Hergt G, Pearce J and Smith I $1997{ }^{238} \mathrm{U}^{230} \mathrm{Th}$ disequilibria, magma petrogenesis, and flux rates beneath the depleted Tonga-Karmadec island-arc; Geochim. Cosmochim. Acta 61 4884-4885.

Wanjari N, Asthana D and Divakara Rao V 2005 Remnants of early continental crust in the Amgaon gneisses, central India: Geochemical evidence; Gondwana Res. 8 589595.

Wilson M 1989 Igneous Petrogenesis: A Global Tectonic Approach; Unwin Hyman, London, 466p.

Yedekar D P, Jain S C, Nair K K K and Dutta K K 1990 The central Indian collision suture; Geol. Surv. India Spec. Publ. 28 1-43. 